\title{
VEZA: AN INFORMAL NETWORK OF TOURISM ENTREPRENEURS
}

\author{
ABSTRACT \\ This longitudinal research positioned at the juncture of tourism, entrepreneurship and \\ transition economies studies investigates the specific informal personal network veza of \\ tourism entrepreneurs. The study discusses the triggers of network formation and their role \\ and utilisation through the entire business lifecycle. Findings demonstrate that veza ties \\ have a dual role in the lifecycle both as main facilitator of entrepreneurial activity and as \\ driver of success of entrepreneurial ventures by providing necessary resources and \\ overcoming barriers in a turbulent institutional environment. This study contributes to \\ tourism social sciences by providing an integrative framework to study the emergence, \\ formation and utilisation of entrepreneurial informal networks in tourism in transition \\ economies.
}

Key words: informal personal networks; veza; favours; tourism entrepreneurs; small firms

\section{INTRODUCTION}

This paper aims to investigate a specific informal personal network, veza, which has grown up as a result of socio-economic transformations in the transitional environment of the former socialist economy of Central and Eastern Europe (CEE) Croatia. Personal networks consist of a variety of relationships, which include acquaintances, friends, family, employees and business friends (Jack 2005). Although the terms 'personal', 'social' and 'informal' networks are often used as synonyms in the literature, we identify informal networks as a distinct form of personal network. We define them as alternative forms of regulation operating often outside the norms of the state. They serve as an alternative social mechanism for supporting economic interaction where formal institutions are either non-existent or ineffective. Informal networks are characterised by reciprocal exchanges of favours, they are intentionally formed and informal relations are always cultivated. Veza represents a nuanced form of personal network and is defined here as an informal egocentric calculative network built on economic exchange rather than social commitment operating on the basis of exchange of favours. Research questions are explored as follows:

1. What are the triggers of veza formation and how do entrepreneurs form veza?

2. Does veza affect the entrepreneurial process and, if so, what outcomes does it bring to tourism entrepreneurs?

The interconnection between entrepreneurs and personal networks has been examined by tourism, entrepreneurship and transition economies literature and this research is positioned at the juncture of these three fields. While a significant body of research investigates entrepreneurial networks, there are still unresolved questions and gaps which call for further investigation. Tourism literature has given primary attention to destination level and policy networks (van der Zee \& Vanneste, 2015) despite entrepreneurs being recognised as primary facilitators for tourism destination development (Thomas, Page \& Shaw, 2011). For tourism entrepreneurs, personal 
networks are of crucial importance and call for more engagement: 1) given the nature of the tourism product/service offered and consequential lack of differentiation, cooperation among tourism entrepreneurs is necessary (von Friedrichs Grängsjö \& Gummesson, 2006); 2) most tourism firms are small in size and may suffer from both liability of newness and smallness, making tourism entrepreneurs dependent upon networks for survival (Strobl \& Kronenberg, 2016); 3) tourism entrepreneurs are faced with significant growth challenges lacking not only capital but knowledge and skills which they may obtain through networks (Ahmad, 2014).

A substantial body of entrepreneurship literature exists regarding entrepreneurial networks (Slotte-Kock \& Coviello, 2010). Several studies conducted across western economies demonstrate the role of networks for entrepreneurs, such as, providing emotional support, developing business ideas, providing information and advice, and access to resources (for example, Lechner \& Dowling, 2003; Zhang, 2010). However, understanding of entrepreneurial personal networks has been developed around social, reputational, co-opetition, and marketing networks, and knowledge, innovation and technology networks (Lechner \& Dowling, 2003) while other types of personal networks, such as informal, have not received appropriate attention. In extensive reviews of the network research in entrepreneurship researchers acknowledge four important shortcomings limiting understanding and requiring further examination: 1) largely focused on high growth industries, technologically intensive firms or a group of industries (Hoang \& Antoncic, 2003) without considering possible industry effects (for instance different resource requirements or entrance barriers which imply different utilization of network ties); 2) most network research focused on start-up and early stages of the business lifecycle (Greve \& Salaff, 2003), while complexities associated with other stages and business growth in particular are less understood (Anderson, Dodd, \& Jack 2010); 3) studies preoccupied with examining structural features of networks such as density or centrality while content of the relationship is less understood (Slotte-Kock \& Coviello, 2010); 4) assumption that entrepreneurs utilise networks to overcome resource challenges but other triggers of network configuration and forms of networks are underexplored (Hoang \& Antoncic, 2003).

Finally, transition economies literature identifies specific forms of informal personal networks, such as blat in Russia and guanxi in China. There is no appropriate translation nor unified meaning, but both blat and guanxi refer to a set of informal reciprocal practices between individuals to obtain goods and services or to skirt formal procedures with the implication of exchange of favours (Ledeneva, 2008). However, understanding the specific role of informal networks in the business process remains an ambiguous and complex issue since transition economies literature has largely focused on architecture of identified informal networks and definitional issues (Hsu, 2005). For entrepreneurs in transitional economies, informal networks are very important and there is a need to broaden the scope of research since: 1) in turbulent environments, informal networks may act as substitutes for non-efficient formal institutions (Michailova \& Worm, 2003); 2) entrepreneurs experience significant difficulties accessing resources during all business stages and search for alternative sources to mobilise resources (Peng, 2004); 3) in Western economies entrepreneurs seek legitimacy from well-regarded individuals or firms to reduce risks associated with smallness and newness (Strobl \& Peters, 2013), whereas this option may not be available to entrepreneurs in transitional economies (Batjargal, 2006); 4) assumption that influence of informal networks decreases as formal 
institutions develop, but limited evidence suggests informal practices tend to persist (Horak \& Klein, 2016).

Croatia is selected as an empirical setting for the investigation as the country recently faced economic and social transformations from socialism to capitalism and admission to European Union (EU) membership. In consequence, entrepreneurial activity and emergence of small tourism firms have all grown significantly and provide a relevant context for the investigation of the role of personal networks in the entrepreneurial process (Peng, 2004). In order to explore the phenomenon in the particular socio-economic context, a qualitative longitudinal study with indepth interviews as the primary data collection method was chosen, a customary approach for such a research position (Strobl \& Kronenberg, 2016).

This paper contributes to tourism entrepreneurship literature and more broadly to business network theory in three aspects. Firstly, offers detailed insight into new type of entrepreneurial informal network veza, triggers for activation, role in entrepreneurship process and development in time. Second, study demonstrates that besides common view personal networks are important as provide access to resources, information and advice, the identified networks made entrepreneurship possible during times when formal institutions were inadequate. Therefore, their role goes beyond resource and support provision. Third, contrary to most previous studies, this research focuses on the entire business lifecycle and a specific sectoral context. Findings show that tourism entrepreneurs rely on informal personal networks throughout the entire lifecycle and their reliance on those networks does not decrease through the lifecycle nor over time. By integrating the theoretical lens of network research and limited tourism entrepreneurship literature on networks, the findings have significant potential to contribute to generic entrepreneurship and management research (Thomas et al., 2011).

\section{ENTREPRENEURIAL PERSONAL NETWORKS: CONTRASTING DIFFERENT PERSPECTIVES}

The number of tourism entrepreneurship studies has increased significantly (Thomas et al., 2011). Besides entrepreneurial characteristics or motivation to enter into entrepreneurship (Ahmad, 2014; Ateljevic \& Doorne, 2003), the studies started to embrace a range of different issues, such as: social entrepreneurs and their impact on destinations (Kimbu \& Ngoasong, 2016) or importance of social capital (Zhao, Ritchie, \& Echtner, 2011). However, in the most recent overview of research into tourism networks, van der Zee and Vanneste (2015) demonstrate many studies have focused on the destination level and policy networks whilst research on entrepreneurial networks is very explorative in nature and has not received in-depth attention. Thomas et al., (2011:972) argued similarly claiming that the lack of research is rather surprising given small entrepreneurial firms dominate the tourism industry, rely on informal networking practices extensively and 'networks play important and multifarious roles in the lives of ownermanagers'.

Two clusters of studies explore individual networks of tourism entrepreneurs. Firstly, studies which research tourism entrepreneurs in general, such as their characteristics or management practices (for example, Ahmad, 2014; Bosworth \& Farrell, 2011). To an extent, such studies also 
probe whether tourism entrepreneurs participate in different types of formal/informal networks or look for specific business situations when entrepreneurs utilise their networks. For instance, Bosworth and Farrell's study (2011) conducted among in-migrant owners of small tourism firms in rural England found that investigated entrepreneurs utilise their networks to: discuss new business ideas and opportunities; access resources; as a tool to embed themselves into local communities. Tucker's (2010) longitudinal study among peasant entrepreneurs in Turkey found entrepreneurs in close and embedded communities avoid any links with organisations outside the community and rely on ties within the village.

The second cluster of studies investigated tourism entrepreneurs and their networking practices explicitly (for example, Hsu, Liu, \& Huang, 2012; Lynch, 2000). One common finding is entrepreneurial reliance on personal ties. For instance, Strobl \& Kronenberg's (2016) study in Austria found that although entrepreneurs change their networks through the business lifecycle from very local ties to industry specific formal organisations, they prefer personal ties. Mottiar (2016:213) found that Irish rural tourism entrepreneurs had strong preferences for informal networking with those players they know personally. A principal motivation to engage in such networking practices was entrepreneurial recognition of the importance of their local area and awareness that 'survival and success is embedded in... [that] of the destination'. Zhao et al.'s (2011) study showed structural social capital (number of social ties with different actors) of tourism entrepreneurs in China is positively related to the entrepreneurial decision to start a business and probability of running it efficiently. Besides these attempts, we know little about individual tourism entrepreneurs and their engagement in different networking practices. Limited evidence exists on the configuration of these networks or different types of relations that can exist. This research starts to address the gaps.

The entrepreneurship field has witnessed a marked increase in studies investigating entrepreneurial networks (Hoang \& Antoncic, 2003). Personal networks significantly influence entrepreneurial activity and affect different stages of business formation and development (Zhang, 2010). Networks consist of various relationships thought to variously improve likelihood of success through the business development stages (Evald, Klyver, \& Svendsen, 2006). The entrepreneurial process can be observed across a range of stages, such as idea generation, opportunity recognition, marketing, planning, financing and growth, usually classified as opportunity, set-up and establishment stages (Bhave, 1994).

The entrepreneurship literature has paid growing attention to types of relations most effective for entrepreneurship and how the role of personal networks evolves throughout the phases of entrepreneurial development (Lechner \& Dowling, 2003). The literature has demonstrated the considerable significance of personal networks in the early stages, where entrepreneurs rely on a small group of close friends and family members for business advice or to acquire resources to start the venture (Zhang, 2010). Entrepreneurs very often utilise family links to allow them to identify potential entrepreneurial opportunities (Jack, 2005), whereas resources and skills are usually found within personal networks with former colleagues, industry professionals and employees. Such reliance on personal ties is a consequence of the significant challenges faced by entrepreneurs arising from uncertainty of business success (liability of newness) and due to information asymmetry problems. Entrepreneurs typically understand the likelihood of business success better than outside evaluators (Shane \& Cable, 2002). Furthermore, it is very likely that 
entrepreneurs will seek legitimacy to reduce risks associated with liabilities of newness and smallness by associating with well-regarded individuals (Anderson et al., 2010).

An increased number of activities in the set-up stage, such as a need for specific professional advice and support, may significantly enlarge entrepreneurial personal networks; entrepreneurs may still rely on family and friends, but will also search for instance, for former and new business contacts and friends of friends (Evald et al., 2006). Jack (2005:1250) found that personal networks supported overall business activity by 'becoming resource suppliers, business generators, market expanders and reputation enhancers.' Although the size and importance of personal networks may decrease over time (Evald et al., 2006), in the establishment stage these networks 'are an entrance ticket for the creation of future options' (Lechner \& Dowling, 2003:17) and for business growth. It is very likely that in this mature stage entrepreneurs will reduce their reliance to a smaller subset of their personal networks, such as special and close business contacts (Greve \& Salaff, 2003).

From early 1990s, private entrepreneurship has progressed in the former socialist economies of CEE. The transformation these countries experienced was complex and involved both economic and fundamental social changes (Smallbone \& Welter, 2001). The need to develop a private business sector by allowing entrepreneurs to create their own businesses was a major challenge. Entrepreneurs were additionally constrained by an underdeveloped institutional framework, poor enforcement of property rights, considerable corruption, and by an intrusive and hostile business environment. Conducting business in such environments has become explicitly related to the availability of informal personal networks, such as blat in Russia and guanxi in China, which have received scholars' attention (Peng, 2004).

No consensus exists regarding the translation and definition of guanxi and blat, and multiple interpretations exist (Hsu, 2005). Blat is usually defined as the system of informal contacts which acted as an alternative mechanism for overcoming rigidities and obtaining consumer goods and services under the Soviet economy rationing system (Ledeneva, 2008). Guanxi is more complex (Fan, 2002) referring to a specific interpersonal relationship which can be established when two or more persons have a commonality of shared attributes, origin or identity. Fan (2002) argued guanxi is a social relationship used instrumentally with obligation to act reciprocally. Both blat and guanxi utilise a web of connections to obtain advantages in personal and organizational relations (Ledeneva, 2008). Blat is identified as instrumental in starting up businesses, as personal networks with government officials enabled Russian entrepreneurs to overcome institutional barriers, such as, property and business registrations and protection from rentseeking officials and mafia members. Entrepreneurs having personal ties with bankers is a crucial factor for obtaining privileged loans (Batjargal, 2006). Similarly in China, utilising guanxi to bypass inadequate formal and financial institutions (Peng, 2004). Therefore, it became possible for someone with very few resources but well-developed personal networks to start a small business. Unsurprisingly, blat and guanxi are portrayed as substitutes or compensatory mechanisms for weak institutional support (Fan, 2002). Entrepreneurs, in order to manage a volatile business environment, use personal networks to enforce property rights, reduce uncertainty and lower entry barriers. The literature assumes that once institutions are established, the role of informal networks will cease to exist, but limited evidence indicates these networks 
may flourish, even in environments with firmly established formal institutional frameworks (Horak \& Klein, 2016).

However, few attempts reveal the role of informal networks in all stages of the entrepreneurship process in transition economies. Guo \& Miller (2010) found Chinese entrepreneurs intentionally enlarged their guanxi networks throughout the entrepreneurial process. In the opportunity stage the network was small, consisting only of family members and close friends. In the set-up stage the guanxi network grew to include governmental officials, key clients and bank investors. In later stages of business development, they are portrayed as 'large and indefinitely expanding' (Guo \& Miller, 2010:275). Studies conducted among Western economies demonstrates the opposite picture as investigated entrepreneurial networks are either more calculative and economic in the later stages of the business lifecycle (Strobl \& Kronenberg, 2016) or entrepreneurs even reduce their networks and spend less time networking (Evald et al., 2006). Ledeneva's (2008) research similarly demonstrates that the blat network does not reduce in size, but contrary to guanxi, entrepreneurs in Russia do not grow their network beyond a certain limit. Rather, entrepreneurs navigate from a narrow circle of trusted people (svoi liudi) to a wider circle of 'useful' people (nuzhnyil liudi). This corresponds more closely to observed practices in Western economies, where entrepreneurs move from personal relationships to dyadic economic interactions (Hite \& Hesterly, 2001).

This review finds that: 1) understanding of the entrepreneurial personal networks is divided between the mainstream (western) entrepreneurship literature and the 'other' research fields, and 2) research on informal networks is still in its infancy. By investigating veza through a holistic and more inclusive view of informal networks, our study aims to extend the existing knowledge base upon which an integrative framework to study the emergence, formation and utilisation of entrepreneurial informal networks in tourism in transition economies will emerge.

\section{ENTREPRENEURSHIP AND TOURISM DEVELOPMENT IN CROATIA}

Part of former Yugoslavia (1945-1991), Croatia was a socialist republic with a strong communist ideology. Entrepreneurship was mainly forbidden during the Yugoslav period (Kovac, 1990). Croatia was the most visited destination within former Yugoslavia and the tourism industry was growing rapidly. In 1974 the Yugoslav government permitted the start-up of small businesses (up to five employees) in tourism and agriculture and a significant number of owners of summer houses started to rent them out (Ateljevic \& Doorne, 2003). Despite such a possibility, the negative attitude towards entrepreneurship persisted. The Communist party claimed individuals pursued an entrepreneurial career because they were incapable of securing a job in a state-owned organisation (Kovac, 1990).

From 1991, Croatia encountered considerable social and political obstacles that significantly held back the transition process. First, war with Serbia led to enormous human and financial losses. Consequently, a significant proportion of accommodation capacities was destroyed or utilised as homes for refugees. Secondly, inadequate privatisation policy enabled enormous frauds by privileged individuals called entrepreneurs (Simic Banovic, 2015). The characterisation of the entrepreneur was negative as they were perceived as privileged criminals. This situation caused a significant decline in entrepreneurial activity and was synonymous with lack of trust in public 
institutions and increased association with corruption.

The tourism industry, dominated by small and medium sized firms, steadily recovered after the civil war ended in 1995, and now contributes more than 25\% of GDP (WTTC, 2018). Despite many positive changes leading to Croatian accession to the EU in 2013, overall entrepreneurial development is still slow, reflecting transitional turbulence concerning high administrative barriers, finance accessibility, and the overall position of entrepreneurs in society. Nevertheless, an increasing number of people overcome these formal and informal institutional barriers and the rate of entrepreneurial activity and number of small and medium sized businesses has grown steadily over the last two decades (Singer, Šarlija, Pfeifer \& Oberman Peterka, 2018). Smallbone $\&$ Welter (2001) argued that in the former transitional economies of CEE, networks emerged as an alternative mode of governance, which enabled entrepreneurs to overcome institutional inefficiencies. Through detailed longitudinal studies, the role of different informal networks can be understood and enhanced.

\section{RESEARCH METHODS}

The first study was undertaken winter 2006/07 and the second winter 2016/17. As customary with qualitative research, purposive sampling was employed (Bosworth \& Farrell, 2011). Evaluation criteria of dependability, credibility, confirmability and transferability (Lincoln \& Guba, 1985) were followed. Dependability relates to the detailed description of the overall process, inclusion of atypical cases (for instance returning migrants in this study) and participants' life situations. Credibility implies that understanding of the phenomenon (veza) will occur if the informant is part of the problem area (entrepreneurs who have utilized veza tie). Two major considerations determined the sample. First, several experts on the Croatian economy and entrepreneurship were asked to identify the sectors and possible regions where we could gain access and investigate the role of entrepreneurial networks. They suggested tourism, specifically the hotel sector, since the largest number of independently owned businesses is present in that sector within the coastal area of Splitsko-dalmatinska county. Second, at the time of the first study, Croatia did not have up-to-date and coherent databases of small tourism firms. The only up-to-date source was the National Hotel Classification (generated by the Ministry of Tourism), which served as a starting point to identify hotels, their size and ownership.

For the sample frame, the Croatian Ministry of Tourism definition was employed i.e. one with 40 or less letting rooms. Using a semi-structured flexible interview guide, 37 hotel entrepreneurs were interviewed. The research stopped when theoretical saturation occurred (Eisenhardt, 1989). Table 1 provides comparative information for analysed entrepreneurs, which adds to the study's dependability and credibility. Interview questions were structured around four key themes: life history and motivation to start a business; formal and informal institutions for entrepreneurship; networks; business lifecycle and operations. These themes were informed by the literature discussed as offering comprehensive insight into the specific tourism context, transitional environment and consequently the networking process and the networks formed. Interviews averaged 90 minutes, often followed by informal discussions, which provided an opportunity to better understand the context in which entrepreneurs operated. After each interview reflective remarks were noted in a research diary. 
Longitudinal design enables us to investigate whether identified personal networks were unique to the transitional period or whether they are embedded in the entrepreneurial practices and have consequently developed over time. All previous interviewees were contacted and all were in business. Although none of the entrepreneurs rejected the invitation, 26 interviews were conducted due to conflicting schedules and absence. Interviews lasted approximately 40 minutes and focused on two main themes: the networks and the environment for entrepreneurship. These themes were the focus of the interview as the main aim was to understand whether entrepreneurs still utilise veza ties and in which business stages and whether veza still operates as observed a decade previously. So, instead of asking 'please can you outline the most significant barriers for entrepreneurial activity?' (such as getting permits, registration of ownership etc), we would ask 'do you still find that eg slow administration is the most prohibiting factor for entrepreneurial activity?'. We would also ask probing questions, such as 'are there any other factors which are more recent?' 'How did they affect you and your business?' We would continue with related questions, such as 'Do you utilise veza to overcome [outlined issue]? How do you form veza tie? (we also tested answers provided during the first study).

All interviews were conducted in Croatian, audio recorded and transcribed. Data analysis was driven by framework analysis, comprising six stages: familiarization; identifying a thematic framework; indexing or coding; charting; mapping and interpretation (Ritchie \& Spencer, 1994). Stages are interconnected and the whole process requires moving backwards and forwards between stages asking constantly 'what is going on here?' Familiarization occurred through iteratively reviewing the data and enabled the development of in-vivo codes or 'emergent issues' attempting to use participants' own words to describe a key aspect of the described topic. For example, one emergent issue was 'favours' used to describe the operating mechanism of the identified personal network.

Confirmability refers to the degree that results can be confirmed by other researchers. We adopted two measures as suggested by Lincoln \& Guba (1985). First, all three researchers dealt separately with a selected number of interviews and constantly compared the data, assigned codes and overall understanding of the identified codes. Second, code-recode procedure was followed meaning that after coding a first set of interviews (five), the researchers waited a couple of days and recoded the same interviews and compared the data. A round of first-order coding was followed by a further round of second-order coding, where, after numerous iterations, ten master codes were developed. In the subsequent analytical stage care was taken to sort coded text segments by designated coding categories and to create individual data charts for every theme capturing all cases. This stage of analysis enables the volume of data to be reduced to a manageable size. Where analysis surfaced meaningful connections, master codes were grouped into code families, or meta-codes, which guide researchers in their process of finding answers on their research questions (Miles \& Huberman, 1994). Finally, ten master codes were subsequently synthesised to three meta-codes which guided the analysis. 'Environment for entrepreneurship' explains institutional environment and overall socio-economic transitional and post-transitional context where entrepreneurs operate ('lack of institutional support') and position of entrepreneurs in the society, where entrepreneurs struggled to gain acceptance by the public ('marginalised voices'). 'Business operations' explains the overall business lifecycle, specificities of each stage and how entrepreneurs navigated the stages. 'Informal network - Veza' explains the emergence of 
veza through historical development, triggers of network activation, operating mechanism, utilisation and the role in the entrepreneurship process and entrepreneurs' views and attitudes on veza. Although we also explored other forms of personal and formal networks, veza represented a novel form of network and entrepreneurs demonstrated strong reliance on this form of personal network compared to others identified in the study. Hence, veza was analysed as a meta-code.

Finally, the study meets the criterion of transferability as sufficient detail of the investigated context and the actual fieldwork are provided, so readers and researchers can determine their confidence in transferring results and conclusions to other contexts and situations (Lincoln \& Guba,1985).

\section{FINDINGS}

Table 1 outlines the profile of investigated entrepreneurs participating in both studies. Returning migrants (noted as RM in the table) are those entrepreneurs who emigrated due to political or economic reasons and returned in the 1990s, after the split of former Yugoslavia. Almost all participants hold a university degree (mostly outside tourism) and had previous entrepreneurial experience in a range of sectors, such as finance, accounting, construction and tourism. Only three entrepreneurs were novice $(\mathrm{H} 2, \mathrm{H} 31, \mathrm{H} 36)$ while all others were either portfolio or serial entrepreneurs. The majority employs between nine and nineteen full-time employees.

\section{[TABLE 1 ABOUT HERE]}

Entrepreneurs (or their families) who started small enterprises under socialism reported that they could not form any personal networks that would provide help with their businesses. For instance, even if friends or relatives were influential in the Communist party, entrepreneurs could not benefit from those personal networks. Entrepreneurs advised that being an entrepreneur during the socialist period meant 'you are an enemy of your country'(H5), that they had no legal security and faced significant difficulties:

After the reforms in 1971 my family wanted to open a restaurant..., but the state and the authorities forbade us. We almost started to work, invested all the money we had but they literally took it away from us! (H23)

Entrepreneurship development following the fall of socialism was a major preoccupation for the Croatian government. Many efforts were misguided and provided little benefit. All interviewed emphasised on-going business environmental challenges significantly hindering their entrepreneurial activities, particularly: 'lack of institutional support' and 'marginalised voices'. Lack of institutional support relates to the underdeveloped institutional framework characterised by high administrative barriers for entrepreneurship, undefined property rights, high levels of corruption and high levels of taxes and impositions. 'Marginalised voices', as public perception of entrepreneurs is even more inhibiting for entrepreneurship development, since it reflects the ongoing prevalent influence of the transition period when entrepreneurs were seen negatively by society. All entrepreneurs reported improvements during the observed period in the area of administrative barriers, corruption and historical legacies but the main issues identified are still seen as primary inhibitors of entrepreneurial activity: 
Administration is a huge problem..., I got my business licence a couple of months ago and I applied 10 years ago. I am considering expanding but I... need more than

50 different documents, permissions, licences, which are impossible to obtain! This has forced me to go into politics but this did not change anything (sighs), administration is too powerful...(H4)

... definitely much easier to start a business these days but we are still struggling with different permits and licences.(H12)

Society sees entrepreneurs as rich people, even they may question the origin of our money... It is also believed that we are so influential that we can change laws to suit our own interests. $(\mathrm{H} 21)$

During the transitional environment of Croatia (from 1995) where formal institutions were yet to be established and entrepreneurship had to gain societal legitimacy, entrepreneurs started to cultivate and rely heavily on informal personal networks called veza, translated as a connection or bond between people. Entrepreneurs describe veza as 'acquaintance with people having an important position in society.' This characterisation relates to the power these people have, either in the public or private sector, when it comes to overcoming administrative barriers or securing business permits. Veza represents an acquaintance with people employed in local authorities and different state bodies, directors of the large state owned companies or officials in the bank. Therefore, veza ties are not based on kin or family contacts. They involve a broader circle of people, who are not mutually connected. As one entrepreneur explained:

Veza is so powerful... in one day literally people you have veza to can decide whether you can start working or not, or whether you will get a construction permit to start building your hotel. But you cannot rely only on veza with one person, you need different people in different positions, if you want to deal with entrepreneurship. For instance, my first veza to someone helped me to legalize the land ownership. Then I had to search for veza to another person who secured me a construction permit.(H36)

Entrepreneurs establish veza networks through two mechanisms (Figure 1). First, they may already have a direct acquaintance with individuals in a position to solve their issue and utilise them to establish a veza tie (V in Figure 1). This direct relationship, which happens very rarely, is referred to here as an inner circle. Second, they may establish veza to people through an extended circle of 'friends of friends', which is the main mechanism of veza formation. A member(s) of this outer circle acts as a mediating mechanism to the veza person, or includes the person/people with whom veza ties will be established. For example, if an entrepreneur E wants to establish veza tie to person $\mathrm{S}$, then $\mathrm{E}$ seeks out a member of his or her outer circle of 'friends of friends', for instance person $\mathrm{C}$, who knows $\mathrm{S}$. The veza tie will be formed only between entrepreneur $\mathrm{E}$ and person S. Therefore, in terms of network structure, veza is based on dyadic relationships and people who entrepreneurs have veza to are not linked to each other in a particular veza network. These dyadic veza relationships do not involve long-term obligations and involvement, and are not classified as 'friendships'. However, they are based on the favour exchange mechanism hence 
bidirectional relationship. After the favour is returned, individuals are not in contact anymore. In terms of obligations, there was no substantial difference between the inner and outer circle. If the entrepreneur seeks a favour again from person S, the contact won't be mediated by person $\mathrm{C}$ but instead made directly. Interestingly, while entrepreneurs talk among themselves about veza ties, they never share details as veza ties are seen as rare and valuable resources.

Veza operates on the basis of exchange of favours, but not material gifts or resources and this characteristic has not changed over time. Entrepreneurs reported a range of favours they had to return, for instance, to secure a place at high school or university. Particular characteristics of veza are that a third party does not mediate a return of favour and that reciprocity is not disguised by significant time delays. Therefore, both entrepreneur and the person s/he has veza to expect that the former returns the favour within a reasonable amount of time. Once the entrepreneur returns a favour there will be no further contact or affiliation between the two parties, unless the entrepreneur seeks veza's favours again:

It works very simply, once you have veza, your problem will be sorted out very quickly. I had veza to a person who helped me to legalize the ownership of my business premises and this was sorted in a month. But you know we are not friends and we will never be (laughs), I had to return this favour. My wife works for the large water supply firm and the person could not get her summerhouse connected on the main pipeline. So we sorted it out for her. That's it, one favour for another.(H3)

Importantly, exchanges never involve monetary payments. Entrepreneurs explain that bribery and veza are conceptually distinct. For entrepreneurs, veza ties are something that is present in everyday business activity and the practice of creating such personal ties is perceived as 'normal' and positive:

No, no, these are two completely different things. People will directly ask you for money if they work on a bribe principle, you know how much their service will cost. But veza is not like that, money was never mentioned and I cannot even count how many times I had to cultivate and use veza in this business. For me, and I believe a majority of other entrepreneurs will tell you the same, we would not be able to start and run our businesses if we did not have veza. $(\mathrm{H} 27)$

Veza plays a powerful role in the entrepreneurial process. Although not significant in providing entrepreneurs with the ability to identify potential opportunities for entrepreneurship, they recognise veza is crucial in the start-up, establishment and business growth stages.

During start-up a key action performed by veza was elimination of institutional deficiencies endangering entrepreneurial endeavours. For instance, veza was instrumental in accelerating: business registration process, obtaining construction permits and legalising property rights. Speedy elimination of barriers implies that entrepreneurs can start running their businesses at the time identified as right, as opposed to some later time when the market might have become saturated. Although entrepreneurs reported some improvements over the past decade, the 
legalisation of private ownership is still the most significant barrier. As one entrepreneur illustrated:

I bought the land for a hotel, very expensive land on a seaside location. When I wanted to collect the ownership document I discovered in the land registry that someone else registered as the owner after I bought the land! My land could be sold to someone else and I could do nothing about it. I luckily established veza with a person who sorted it out ..., otherwise who knows what might have happened.(H26)

Entrepreneurs argued that despite attempts by the government to implement market reforms at the beginning of the transition period, veza created the basic necessary institutions and helped people engage in entrepreneurship. Veza ties were the main facilitator of entrepreneurial activity in the early years of transition and without those ties entrepreneurs would not be in position to enter into entrepreneurship. The importance of veza is further emphasised in the returning migrants' case. Returning migrants suffered from weaker or non-existent veza ties, making it even more difficult for them to start a business. Returning migrants were not embedded into the local area and lacked social and kinship networks which significantly reduced their access to veza ties. The most difficult period was until around early 2000, when the existence of veza ties was a precondition for entrepreneurial activity. Returning migrants reported:

We returned back immediately when the war was over and had more than enough capital to start hotel business, which was our dream for a very long time. It turned out we could do nothing, our every attempt to obtain different permits or even start a company... it was like walking in a minefield. Everyone was talking, just get veza ties, but I did not know anyone here, I had no friends and all my family was abroad.(H8).

We saw the opportunity, wanted to invest, but honestly we were naive. Nothing works, the reforms jeopardise entrepreneurship instead of helping it. Because formal institutions do not work, you need veza for everything. I don't know anyone here, I was away for a long time, and I could not establish veza to anyone here. As a result, I needed 8 years just to legalise the ownership of the land I bought and 6 years to obtain a construction permit. (H15)

Entrepreneurs reported that the role of veza as a necessary condition to engage in entrepreneurial activity started to lose significance in recent years, as formal institutions became more efficient. However, entrepreneurs still rely on veza ties in order to accelerate procedures or bypass inadequate regulations.

Do you know how complicated it is to select a name and how long you have to wait for a judge to approve it [company's name]? It's a nonsense, I tell you. I managed to find a veza tie to a judge and luckily this was approved the same week. $(\mathrm{H} 2)$

Besides their role in the start-up stage, entrepreneurs significantly rely on veza during the establishment stage and both the role and utilisation of veza tie did not change significantly during the investigated period. In particular this usage relates to marketing and sales activities. Here, veza is used more strategically to circumnavigate competitive and resource disadvantages, 
rather than institutional barriers. Entrepreneurs may aim to increase their competitiveness in the market by improving hotel facilities and services. For instance, building pools, conference rooms or leisure centres. Given financial restrictions imposed by banks and underdeveloped non-bank financial institutions during the early transition period, such as microfinance institutions, entrepreneurs used veza to speed up the process of obtaining bank loans for improvements. Entrepreneurs also reported that they find it difficult to make direct contact with large suppliers and distribution channels, which can offer better terms of trade. Interestingly, entrepreneurs argue that these barriers are a direct consequence of their small size, which limits their negotiation power and causes an unfavourable position in the marketplace. This barrier was significantly emphasised during the second study, as the number of small hotels in the destination increased. It was crucial to establish relationships with key players in the destination in order to offer a more competitive product/service. Veza is utilised not only to make contacts with suppliers, but also to arrange favourable contracts for entrepreneurs and to negotiate with distribution channels for lower commission rates:

I need to work with travel agencies, I am based on the island and need to cover months outside the peak season. But do you know how much they would charge me? $30 \%+i$ s their commission rate! (upset). Even if I have 100 rooms this would be unsustainable. I tried to fight, but without success. When I almost quit, my veza person sorted it out and I signed a contract with the agency for this year where they will charge me $15 \%$ of my room price. $(\mathrm{H} 6)$

Veza is also significant in the business growth stage. The growth stage was the most complex for entrepreneurs, as besides careful planning and investment, entrepreneurs were faced again with institutional barriers. During the growth stage, the role of veza becomes more complex, and is used both to overcome resource disadvantages, such as access to bank finance, and institutional challenges, such as business registration or acquisition of various business permits. Reflecting the importance of veza in this stage, one entrepreneur reported:

...we are restricted in so many ways...I wanted to expand my hotel several years ago. I saw that I can grow and on top of this the government had a good credit scheme with a very low interest rate when I applied. It was like 'déjà vu'... I needed so many licences, approvals... and the loan was a brand new experience... Again, my veza person sorted it all out instead of different state bodies who are responsible for that. I got the licences and a loan but I had to employ his son in my bakery shop (laughs).(H7)

The importance of veza in this business stage is further emphasised by the example of a returning migrant, who had to delay plans because he was not able to secure veza:

...no entrepreneur in this world who started a business... does not think about expanding.... If you don't think and act in this way something is wrong..., you are not a true entrepreneur. However, I had to cancel my growth plans as I could not find veza that would ensure that I don't get stuck with the administration procedures for two years, as was the case with this hotel. I would not repeat the same mistake twice. $(\mathrm{H} 29)$ 


\section{DISCUSSION}

This study has yielded new insights into entrepreneurial informal networks and the findings highlight areas for further discussion. Table 2 summarises the characteristics of veza compared to blat and guanxi and this will be further elaborated below. Also, we will demonstrate how entrepreneurs systematically rely on veza ties through the entire business lifecycle. Consequently, a framework which conceptualises veza development is introduced (Figure 1).

\section{[TABLE 2 ABOUT HERE]}

The study reveals that although veza operates on the exchange mechanism and favour practices similar to other informal networks, there are substantial differences which make it a novel informal network. The most significant differences relate to the drivers for activation. Studies reveal different drivers which stimulate entrepreneurs to activate their personal networks, such as maximisation of individual/business values or maximisation of the value for a family (Greve \& Salaff, 2003). In the case of small tourism firms the trigger may be transition from one family generation to the next or changes in competitive environment (Strobl \& Kronenberg, 2016). The major driver, which motivated entrepreneurs to activate veza in the early years of transition, is the access to entrepreneurship (Figure 1). Veza emerged during the transition period as a necessary condition to pursue business endeavours and has played a significant role in defending property rights and in reduction of transaction costs during market reforms. Although transition economies studies have recognised the role of informal networks as substitutes for inefficient formal institutions (Smallbone \& Welter, 2001), this study demonstrates that informal networks are effectively a necessary condition for entrepreneurial activity to take place and entrepreneurship may be an option only for those who have access to informal networks. Once institutions became more efficient veza was not crucial to access entrepreneurship. However, veza did not vanish, as predicted by the literature (Ledeneva, 2008), demonstrating that informal personal networks are not only a particular characteristic of a transitional period.

Similar to personal networks observed in a Western and transition economies context (Jack, 2005; Michailova \& Worm, 2003), the major operating mechanism of veza is an exchange of favours. However, the literature demonstrates that entrepreneurial personal networks in general and informal in particular, are driven by long-term relations and, besides utility, very often provide emotional support, as found for instance by Kimbu \& Ngoasong (2016) investigating women tourism entrepreneurs in Cameroon. However, veza operates on short-term utilitarian goals only. Network parties only enter into a veza relationship if both parties have something useful for another party and the transaction can be completed without significant time delays. The nature of such an instrumental relationship does not allow for a longer-term relationship, which might include additional support to entrepreneurs, for example, of an emotional nature. This contrasts to both blat and guanxi where parties expect the repayment value to be greater than the original favour value, so that one party ends up in the other's debt and, therefore, has an excuse to set up the next interaction (Hsu, 2005).

The high diversity and dynamics of veza do not emanate from entrepreneurial attempts to develop networks which incorporate a varied range of competencies and contacts, as observed in the 
literature (Mottiar, 2016). Strobl \& Kronenberg's (2016) study shows how entrepreneurs navigate from family networks and local ties to more industry-specific actors and non-local ties. Diversity in veza's case is a consequence of short-term and utilitarian relations which require that entrepreneurs establish veza ties only with those parties who can fulfil a specific need. When an entrepreneur returns the favour, the veza network to a particular person will reactivate only if a new favour is needed.

\section{[FIGURE 1 ABOUT HERE]}

Veza networks are significant for tourism entrepreneurs during the start-up, establishment and growth stages. The importance and novelty of this finding relates to the role and purpose of entrepreneurial informal networks within the context of tourism studies, which have largely ignored the concept of networks outside the destination level (van der Zee \& Vanneste, 2015). Besides a few attempts (Hsu et al., 2012; Strobl \& Kronenberg, 2016), studies do not empirically demonstrate tangible network outcomes along the business lifecycle, nor the ties being used in each business stage. The mainstream literature emphasises the role of strong ties such as family members and reputational networks in the early business stages (Jack, 2005). In the later stages their importance decreases and the network is transformed from strong socially embedded ties to more calculative ties (Hite \& Hesterly, 2001). The tourism literature finds that entrepreneurs either rely on close and personal relationships throughout the lifecycle (Strobl \& Kronenberg, 2016) or navigate from strong to weak ties back and forth (Hsu et al., 2012). However, our study shows that tourism entrepreneurs demonstrate a strong preference towards more calculative and weak ties throughout the business lifecycle. This networking strategy is observed during both the market reforms and in recent years when formal institutions became more efficient.

Various scholars argue that distinctive elements of network governance can create cost advantages in comparison to coordination through market mechanisms (Jarillo, 1988). In our study entrepreneurs did not have this option as market mechanisms did not work. In the early years veza's role during the start-up stage was to enable access to entrepreneurial activity and also to substitute for inefficient institutions. In recent years when formal institutions are present, veza still has a significant role in the start-up stage where it acts as a mechanism to bypass inefficient administration or procedures which slow down considerably the entrepreneurial process, such as obtaining different permits. This finding contradicts literature which postulates that entrepreneurs in early stages seek legitimacy from well-regarded individuals and organisations to minimise risks associated with the liabilities of newness and smallness (Strobl \& Kronenberg, 2016). Veza ties are made with those individuals lower down the pyramid in order to access entrepreneurship or to obtain tangible benefits. Also, this finding contrasts with the view that the role of informal networks will decrease and may disappear once formal institutions are introduced (Ledeneva, 2008). Longitudinal findings demonstrate that the informal network veza is adaptable in its role in the entrepreneurship process while remaining calculative in nature and represents a novel finding. In terms of outcomes, veza is associated only with tangible benefits through the entire lifecycle. The findings indicate that once formal institutions became more efficient, veza ties remained calculative, without shifting their role to provision of intangible resources such as reputation.

Veza's role extends beyond the start-up stage and has significant influence in the entrepreneurial 
process. In the establishment stage, veza ties are activated as a strategic mechanism to overcome resource disadvantages due to the liability of smallness. Hsu et al.'s (2012) study among hospitality entrepreneurs in China found a similar pattern where entrepreneurs relied on political ties in the establishment stage. Therefore, it can be argued that in this stage entrepreneurs may limit their network to useful ties (Greve \& Salaff, 2003). In the growth stage veza ties are activated to overcome complex institutional and resource challenges particular to that stage of business development. Therefore, in the latter stages of business development veza facilitates the success of the venture by overcoming resource disadvantages and increasing the competitive position in the market. Furthermore, veza ties also bypass slow administrative procedures, becoming the main facilitators of business growth. Strobl \& Kronenberg (2016) showed the importance of a reputational network to accomplish growth, as they help entrepreneurs to achieve credibility of their products and service, which is of crucial importance in the service context. In our study, entrepreneurs grew their businesses through for instance, expanding existing or building new hotels, or entering related sectors, such as restaurants or trade. At the same time entrepreneurs were also increasing the quality of the existing products and services (Table 1). Therefore, there was no shift towards reputational networks in this stage but rather veza ties adapted to the requirements of this business stage. Nevertheless, although the role of veza ties changed systematically across the stages of the entrepreneurial process, the ties themselves did not change in terms of structure or activation mechanism. Longitudinal results did not show any changes in the outcomes veza provides and there was no shift from being path-dependent to a network proactively managed by the entrepreneur (Slotte-Kock \& Coviello, 2010).

\section{CONCLUSION}

By positioning this research at the academic juncture of tourism, entrepreneurship and transition economies, this study contributes to tourism social sciences by providing an integrative approach to study the emergence, structure and utilisation of the informal personal network veza in tourism in transition economies. The study's findings are significant for tourism studies, which so far have largely overlooked the tourism entrepreneur and their networking practices.

Notwithstanding early attempts to show the reliance of tourism entrepreneurs on their personal ties (Lowe, 1988) and a common understanding entrepreneurs will avoid formal tourism networks (Thomas et al., 2011), few studies investigate personal networks, their utilisation and benefits they bring to entrepreneurs through the entire business lifecycle (van Der Zee \& Vanneste, 2015). This study demonstrates that existing research has to be interpreted with caution when applied to the tourism industry during turbulent periods. Findings indicate that contrary to previous studies, tourism entrepreneurs rely on informal ties throughout the entire business lifecycle and strategically activate veza ties depending on the stage in the business lifecycle. Hence, the expected shift from socially-embedded to calculative networks does not happen (Hite \& Hesterly, 2001) as tourism entrepreneurs build their informal networks based on economic exchange only rather than social commitment. Therefore, this implies that in order to achieve specific business outcomes through cooperation with other tourism firms (von Friedrichs Grängsjö \& Gummesson, 2006), tourism entrepreneurs in transitional economies activate informal ties instead. Findings also demonstrate that informal networks play a crucial role in overcoming liabilities of smallness and increasing competitiveness. This extends Mottiar's (2016) research which shows a strong preference of tourism entrepreneurs towards informal 
networking. However, veza ties do not include emotional support or provision of intangible resources, which is surprising when compared to the tourism and generic business literature (Strobl \& Kronenberg, 2016).

Despite several studies on entrepreneurial informal personal networks outside the Western context and in particular among the CEE economies, this is the first to our knowledge which attempts to understand and contextualise a specific informal network beyond Russia and China. The findings reveal the unique characteristics of veza, namely its operating mechanism, the nature of relations and activation drivers. Informal networks in transition economies cannot be explained only through favour-exchange practices as previously assumed; we also have to understand their origin, meaning, dynamics and the network relations established. Our analysis challenges a one-dimensional view on the role of informal networks, which assumes that they are substitutes for inefficient institutions and that once institutions are in place, they will vanish (Smallbone \& Welter, 2001). Veza's role proved more complex, by acting as a primary mechanism to access entrepreneurship and also fulfilling the traditional role of networks, such as to secure necessary resources, to enhance sales activities, to negotiate with distribution channels, to overcome the liability of smallness and to facilitate the growth process. Veza is thus also cultivated by the drive to achieve the success of an entrepreneurial venture. Veza therefore has a dual role in the entrepreneurial process and the role of veza changes systematically depending on the business stage.

Our research has several limitations. Although this study conceptualises a new form of informal network, veza appears to be unique to Croatia. To enhance understanding of informal networks and transferability of study's findings requires further research across a diverse range of settings and individuals. Application of a unified theoretical framework would make mutual comparison possible. However, such attempts must be made with caution, as those traditionally used to understand networks, such as Granovetter's tie strength, rely on different premises than the observed informal network. Also, our study discusses only one type of identified network. In terms of future research, more detailed investigation of informal, personal and formal networks and how entrepreneurs navigate between different ties is needed to understand the importance, utilisation and dependence on different ties throughout the lifecycle. Furthermore, our analysis points to significant differences between veza and other informal networks and future research is needed to understand which cultural factors affect network formation and utilisation. Finally, there can be a blurred distinction between informal networks, bribery and corruption (Ledeneva, 2008). Studies are required to investigate whether informal networks are used as a vehicle for corruption and whether those who do not possess such informal ties feel forced to bribe.

\section{REFERENCES}

Ahmad, S. Z. (2014). Entrepreneurship in the small and medium-sized hotel sector. Current Issues in Tourism, 18(4):328-349.

Anderson, A. R., Dodd, S. D., \& Jack, S. (2010). Network practices and entrepreneurial growth. Scandinavian Journal of Management, 26(2):121-133.

Ateljevic, I., \& Doorne, S. (2003). Unpacking the local: A cultural analysis of tourism 
entrepreneurship in Murter, Croatia. Tourism Geographies, 5(2):123-150.

Batjargal, B. (2006). The dynamics of entrepreneurs' networks in a transitioning economy: the case of Russia. Entrepreneurship \& Regional Development, 18(4):305-320.

Bhave, M. (1994). A process model of entrepreneurial venture creation. Journal of Business Venturing, 9(3):223-242.

Bosworth, G., \& Farrell, H. (2011). Tourism entrepreneurs in Northumberland. Annals of Tourism Research, 38(4):1474-1494.

Eisenhardt, K. (1989). Building theories from case study research. The Academy of Management Review, 14(4):532.

Evald, M. R., Klyver, K., \& Svendsen, S. G. (2006). The changing importance of the strength of ties throughout the entrepreneurial process. Journal of Enterprising Culture, 14(01):1-26.

Fan, Y. (2002). Questioning guanxi: definition, classification and implications. International Business Review, 11(5):543-561.

Greve, A., \& Salaff, J. (2003). Social Networks and Entrepreneurship. Entrepreneurship Theory and Practice, 28(1):1-22.

Guo, C., \& Miller, J. (2010). Guanxi dynamics and entrepreneurial firm creation and development in China. Management and Organization Review, 6(2):267-291.

Hite, J. M., \& Hesterly, W. S. (2001). The evolution of firm networks: From emergence to early growth of the firm. Strategic Management Journal, 22(3):275-286.

Hoang, H., \& Antoncic, B. (2003). Network-based research in entrepreneurship. Journal of Business Venturing, 18(2):165-187.

Horak, S., \& Klein, A. (2016). Persistence of informal social networks in East Asia: evidence from South Korea. Asia Pacific Journal of Management, 33(3):673-694.

Hsu, C. (2005). Capitalism without contracts versus capitalists without capitalism: Comparing the influence of Chinese guanxi and Russian blat on marketization. Communist and PostCommunist Studies, 38(3):309-327.

Hsu, C., Liu, Z., \& Huang, S. (2012). Managerial ties in economy hotel chains in China. International Journal of Contemporary Hospitality Management, 24(3):477-495.

Jack, S. (2005). The role, use and activation of strong and weak network ties: a qualitative analysis. Journal of Management Studies, 42(6):1233-1259.

Jarillo, J. C. (1988). On strategic networks. Strategic Management Journal, 9(1):31-41.

Kimbu, A. N., \& Ngoasong, M. Z. (2016). Women as vectors of social entrepreneurship. Annals of Tourism Research, 60:63-79.

Kovac, B. (1990). Politicko-ekonomska uloga poduzetnistva. In D. Njavro \& V. Franicevic (Eds.), Poduzetnistvo: Teorija, politika, praksa (pp. 69-93). Zagreb: Privredni Vjesnik.

Lechner, C., \& Dowling, M. (2003). Firm networks: external relationships as sources for the growth and competitiveness of entrepreneurial firms. Entrepreneurship \& Regional Development, 15(1):1-26.

Ledeneva, A. (2008). Blat and Guanxi: Informal Practices in Russia and China. Comparative Studies in Society and History, 50(01):118-144.

Lincoln, Y. S., \& Guba, E. G. (1985). Naturalistic inquiry (Vol. 75). Newbury Park, CA, Sage.

Lowe, A. (1988). Small hotel survival — an inductive approach. International Journal of Hospitality Management, 7(3):197-223.

Lynch, P. A. (2000). Networking in the homestay sector. The Service Industries Journal, 20(3): 95-116.

Michailova, S., \& Worm, V. (2003). Personal Networking in Russia and China: European 
Management Journal, 21(4):509-519.

Miles, M., \& Huberman, M. (1994). Qualitative data analysis. Thousands Oaks, CA: Sage.

Mottiar, Z. (2016). The importance of local area as a motivation for cooperation among rural tourism entrepreneurs. Tourism Planning and Development, 13(2):203-218.

Peng, Y. (2004). Kinship networks and entrepreneurs in China's transitional economy. American Journal of Sociology,109(5):1045-1074.

Ritchie, J., \& Spencer, L. (1994). Qualitative data analysis for applied policy research. In A. Bryman \& R. Burgees (Eds.), Analyzing Qualitative Data (pp. 173-194). London: Routledge.

Shane, S., \& Cable, D. (2002). Network ties, reputation, and the financing of new ventures. Management Science, 48(3):364-381.

Singer, S., Šarlija, N., Pfeifer, S. \& Oberman Peterka, S. (2018). Što čini Hrvatsku (ne)poduzetničkom zemljom? GEM Hrvatska. CEPOR. Zagreb.

Simic Banovic, R. (2015). (Former) Informal networks as a reflection of informal institutions in East European transitional societies: legacy or opportunism? Equilibrium. Quarterly Journal of Economics and Economic Policy,10(1):179-205.

Slotte-Kock, S., \& Coviello, N. (2010). Entrepreneurship research on network processes: A review and ways forward. Entrepreneurship Theory and Practice, 34(1):31-57.

Smallbone, D., \& Welter, F. (2001). The distinctiveness of entrepreneurship in transition economies. Small Business Economics, 16(4):249-262.

Strobl, A., \& Kronenberg, C. (2016). Entrepreneurial networks across the business life cycle: the case of Alpine hospitality entrepreneurs. International Journal of Contemporary Hospitality Management, 28(6):1137-1154.

Strobl, A., \& Peters, M. (2013). Entrepreneurial reputation in destination networks. Annals of Tourism Research, 40:59-82.

Thomas, R., Shaw, G., \& Page, S. J. (2011). Understanding small firms in tourism: A perspective on research trends and challenges. Tourism Management, 32(5):963-976.

Tucker, H. (2010). Peasant-entrepreneurs: A Longitudinal Ethnography. Annals of Tourism Research, 37(4):927-946.

van Der Zee, E., \& Vanneste, D. (2015). Tourism networks unravelled; a review of the literature on networks in tourism management studies. Tourism Management Perspectives, 15:46-56.

von Friedrichs Grängsjö, Y., \& Gummesson, E. (2006). Hotel networks and social capital in destination marketing. International Journal of Service Industry Management, 17(1):58-75.

WTTC (2018). Travel and Tourism Economic Impact: Croatia. London: WTTC.

Zhang, J. (2010). The problems of using social networks in entrepreneurial resource acquisition. International Small Business Journal, 28(4):338-361.

Zhao, W., Ritchie, J. B., \& Echtner, C. M. (2011). Social capital and tourism entrepreneurship. Annals of Tourism Research, 38(4):1570-1593. 